\title{
Exploring contingent convertible bond alternatives for African banks
}

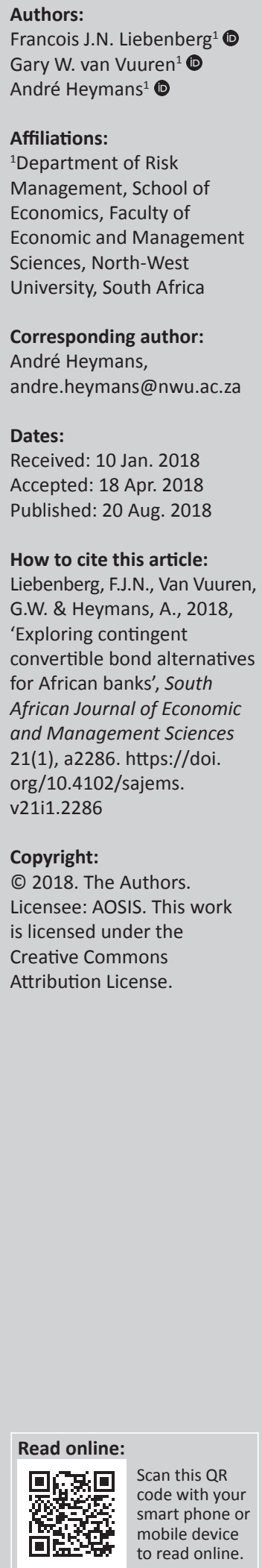

Background: A variant of the contingent convertible bond, first proposed in 2011, is investigated: the Call Option Enhanced Reverse Convertible (COERC). Although issued as a bond, it converts to new shareholder's equity if a bank's market share of capital falls below a pre-specified trigger point.

Aim: COERCs avoid the problems with market-based triggers (e.g. sell-offs and death spirals) due to panic and market manipulation. Banks that issue COERCs have less incentive to choose investments that may be subject to large losses and disincentive problems, associated with the replenishment of shareholder's equity after market declines (also known as debt overhang) are also avoided.

Setting: Proposed amendments to the COERC structure are suggested for the African market.

Methods: The data used were simulated, stylised values for a standard COERC. No market parameters are required, such as equity or debt levels or market volatility. Details of the stylised example are provided in Table 4 and Table 5 in the 'results and discussion' section.

Results: Both examples of floating coupons for COERCS would aid in the objective of issuing a security that is countercyclical in nature, as banks would avoid having to pay coupons in times of distress.

Conclusion: In addition to the recommendations of the Basel frameworks, CoCos have been considered and proposed as an additional measure to promote counter cyclicality in terms of capital composition in banks.

\section{Introduction}

The credit crisis of 2008 triggered global financial distress - particularly in banks. As a direct result, regulators were mobilised to alter banks' capital structure so that losses and bankruptcy costs could be shouldered by the banks' creditors rather than by taxpayers as was the case in most developed markets for the 2008 crisis (Sundaresan 2013). One of the many suggestions put forward by global regulatory authorities was the proposal that banks should implement and install contingent convertible debt $(\mathrm{CoCos})$, which automatically convert into equity when prespecified trigger levels are breached. These triggers could be accounting information based, market price based, or wholly decided by bank supervisors. Whatever the initiating event, the aim is to ensure the automatic recapitalisation of the bank when crises occur to liberate them from the ensuing debt service (and default) payments (Albul, Jaffee \& Tchistyi 2010).

Global CoCo issuance soared post the credit crisis (2009-2014): additional tier 1 capital CoCo issuance increased from US \$2 billion in 2010 to $\$ 93$ billion in 2014. Tier 2 CoCo issuance was stable during these periods at around $\$ 10$ billion, but increased to $\$ 82$ billion in 2014 . Since then (between 2015 and 2018), both types of capital CoCo issuance have stabilised but diminished, additional tier 1 at around $\$ 60$ billion and tier 2 at about $\$ 16$ billion as shown in Figure 1 (Ainsworth 2017).

Early proposals embraced CoCos with regulatory triggers (e.g. Glasserman \& Nouri 2012; Pennacchi 2011; Sundaresan \& Wang 2012). The idea was simple enough: when banks' tier 1 capital ratios fall below a prescribed level, these convertible bonds will convert into equity and recapitalise the ailing bank.

Problems arise, however, because it is unattractive to issue CoCos unless:

- Regulatory authorities deem them sufficiently like equity to qualify as tier 1 capital.

- Tax authorities judge them as sufficiently like debt to permit interest payments to be tax deductible (Calomiris \& Herring 2013). 


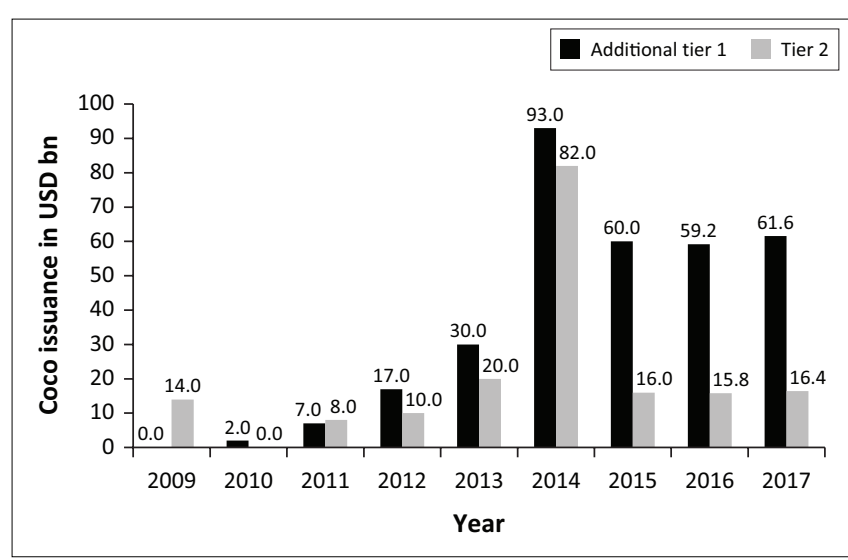

Source: Ainsworth, S., 2017, Global CoCo issuance in 2017 will be on a par with previous year Moody's Investor Services, New York, viewed n.d., available from https://www.moodys. $\mathrm{com} /$ researchdocumentcontentpage.aspx?docid=PBC_1065162

FIGURE 1: Global contingent convertible issuance (in US \$ billion).

Although most European countries and their relevant regulatory and tax authorities recognise this, the Internal Revenue Service (IRS) declined to do so. As a result, United States (US) banks do not issue CoCos (Herring 2017).

Some of these issues were addressed by Liebenberg, Van Vuuren and Heymans $(2016,2017)$ with focus on the unique African financial milieu. The South African Reserve Bank (SARB), for example, deems that CoCos do qualify as tier 1 capital and local tax authorities do judge them as sufficiently similar to debt to allow tax deductible interest payments.

Despite some early successes (Bolton \& Samama 2012; Flannery 2009a, 2009b), however, CoCos based on purely regulatory triggers (or, indeed, market-based triggers) were plagued by problems (Berg \& Kaserer 2015; Sundaresan \& Wang 2012). In June 2017, the sixth largest Spanish (Banco Santander) bank's CoCos experienced considerable losses (RiskConcile 2017; Unmack 2017). Banco Santander's Single Resolution Board (SRB) transferred all shares and capital instruments of Banco Popular Espanol (Banco Popular) to Banco Santander. The CoCo functioned exactly as it should: taxpayers did not pick up the bill for debt instrument investors and senior bond holders were rescued. For subordinated bond holders and CoCo bond investors, however, the SRB decision triggered the decimation of value for $\mathrm{CoCo}$ bond investors who witnessed the value of their initial investment decline by over $60 \%$ in a few weeks. CoCo investors were painfully reminded of the high risks associated with CoCos, masked in good times by the CoCo bond's high coupon.

Other types of CoCo bonds have been proposed whose conversion is triggered when a market value capital ratio is breached, Call Option Enhanced Reverse Convertibles (COERCs). These instruments are promising alternatives as they have several desirable features which circumvent problems that arose with regulatory-based triggers CoCos (Pennacchi, Vermaelen \& Wolff 2014). COERCs are still (2018) relatively new and investors are unsurprisingly reluctant to purchase untested instruments, particularly so

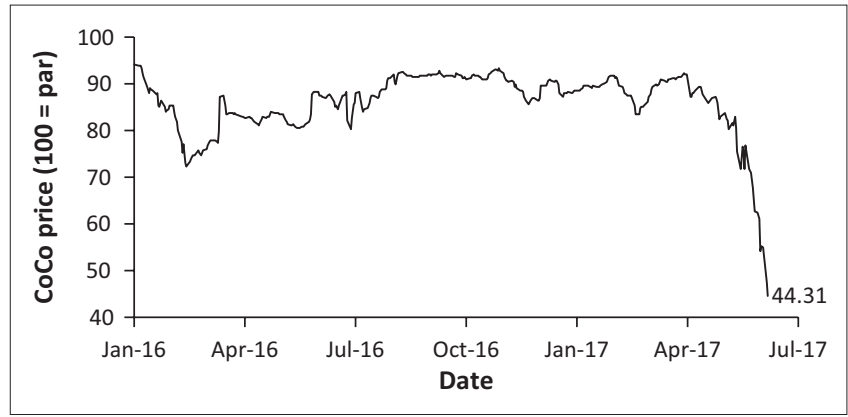

Source: Thomson Reuters, 2017, Online database, viewed 13 May 2017, available from https://www.thomsonreuters.com/en.html

FIGURE 2: Banco Santander $8.25 \%$ contingent convertible price (US dollar).

soon after the credit crisis and - more recently - so soon after the disastrous performance of Banco Popular (and other) CoCos (RiskConcile 2017; Unmack 2017). COERCs, though, have features which might work well in the African bank space - and in this article, some amendments are proposed and examined. Implementation in African markets is subject to regulatory scrutiny and buy-in from both investors and banks, but given the theoretical success of the proposal to date, early signs are promising.

The remainder of this article proceeds as follows, the 'literature study' reviews the available, relevant literature regarding CoCos and the problem of procyclicality in banks. The regulatory response to the 2008 credit crisis is also reviewed here. The 'data and methodology' section presents existing CoCo pricing and valuation approaches and the proposed mechanisms that govern the behaviour of COERCs. The relevant mathematics is dense, but explained elsewhere, so only a numerical example is provided for comparison purposes. The results of calculations are analysed and presented in the 'results and discussion' section, as well as a discussion regarding the theoretical ramifications of COERC implementation in African banks. The 'conclusions and suggestions for future work' concludes the article.

\section{Literature study}

Regulatory bank capital levels increased considerably after the credit crisis which began in 2007. The crisis arose from multiple causes, but an important one was the neglect of capital procyclicality. Contingent convertible bonds were proposed to alleviate this problem. The relevant literature outlining the crisis, the problem of procyclicality and the need for contingent capital is presented below.

\section{The credit crisis}

During 2007 the global economy experienced a credit crisis which had disastrous effects on international financial markets. The reasons behind the crisis are plentiful, however, a principle driver of the widespread crisis was the existence, use and eventually the failure of complex derivative investment instruments (Baily, Litan \& Johnson 2008). These instruments caused an inflation of asset prices beyond their historic trends and due to their complex nature, they were also not priced correctly. As a result, the banks who invested 
and traded in these instruments held more risk than what was anticipated in financial models and the effect of this risk was exposed when many banks filed for bankruptcy. The first bank to tumble was Lehman Brothers who officially applied for Chapter 11 bankruptcy in September of 2008 (De Haas \& Van Horen 2012).

The effect of the Lehman bankruptcy was a global mistrust between financial institutions leading to a drastic reduction in lending and a financial system whose member firms tried to sell off any securitised instruments at any cost. These effects are classic signs of a capital market which is procyclical in nature (Nikolov 2010). In other words, when an economic indicator experiences an increase in value when the economy exhibits economic growth, it is deemed a procyclical indicator and is used as a metric to measure procyclicality. When the procyclicality methodology is applied in analysing the losses suffered during the credit crisis, it is evident that the losses that occurred during the credit crisis, exceeded the gains that were evident in periods when the economy grew, proving the procyclical nature of the financial models used to model the risk of global financial institutions, especially under the Basel II framework employed in the period preceding the financial crisis (Basel Committee on Banking Supervision [BCBS] 2010b; Van Vuuren 2012).

When further examining the procyclical effects, it is evident that the supply side of the financial system, banks lending money, reacted especially negatively to the financial shocks that the global markets experienced (De Haas \& Van Horen 2012). Banks dried up virtually all fund lending to clients, and as such, the broader financial system suffered, as there was no liquidity for businesses with which to operate. In response to this crisis, the Bank for International Settlements (BIS) updated the Basel II regulation with an additional set of requirements, in order for banks to be more prepared for similar crises in the future and combat the procyclicality inherent in previous financial models to some extent (BCBS 2011). This new set of regulations is known as Basel III and is expected to be fully implemented by 2019. The main aim of the newer Basel III regulation is to bolster the amount, liquidity, consistency, transparency and quality of tier 1 capital (BCBS 2010a). Additionally, Basel III also includes a reconstitution of acceptable regulatory capital, enhancements to the amount of capital required for the trading book and also completely new rules such as the amount of required capital buffers and a leverage ratio. These measures are aimed at increasing the required amount of capital from $8.0 \%$ to $10.5 \%$ (even to $13.5 \%$ in specially defined circumstances) (BCBS 2011).

A noteworthy addition in requirements of Basel III is the countercyclical capital buffer (CCB) which aims to directly combat the procyclicality inherent in financial models. The CCB is a mechanism that is designed to bolster the capital ratio up to $13 \%$ when the economy is expanding. The $C C B$, thus, functions mainly at the height of an economic cycle and is designed to discourage excessive credit lending by banks. This measure, however, still remains (2017) a theoretical measure and has not been tested practically to the knowledge of the authors at the time of publication. Real-world scenarios may disprove the theory behind this mechanism as it may not effectively motivate lending in economic cycle downturns, hence the pressing need for regulators to inspect additional countercyclical measures.

\section{Contingent convertible bonds}

An example of an alternatively proposed countercyclical measure is the CoCo, a class of security that possesses both an underlying equity component, as well as a fixed-income producing component. These securities were designed to be loss-absorbing in the sense that they will be issued as bonds but will convert into equity after certain conditions are fulfilled (BCBS 2010a). CoCos behave much like vanilla convertible bonds, but contain fundamental differences. A standard bond which is callable and convertible may be manually converted into a predefined number of the common shares of the issuer at any time, as required by the holder of the bond. This bond is usually also callable by the issuer, in the sense that the bondholder may be requested to surrender the bond to the issuer at a predefined price (Huang 2009). Thus, the bondholder or issuer may choose at will when the contract comes to an end. These bonds are popular due to the higher yields (to attract investors to what are considered non-standard instruments) they offer versus traditional non-convertible bonds (as they carry more risk due to the convertible clause attached to them) and the motivation for conversion (upside versus downside). ${ }^{1}$ The trigger mechanism that results in the conversion of the bonds is where CoCos and vanilla convertible bonds differ.

Glasserman and Nouri (2012) explored CoCos characterised by accounting-based triggers (e.g. the book value of assets), using Merton's structural framework. The conversion to equity was just sufficient to meet the capital requirements and occurred whenever the trigger was reached (assuming the trigger point was greater than the bankruptcy barrier).

Albul et al. (2010) also employed Merton's (1974) structural framework to address capital structure decisions for CoCos. Assuming asset value triggers, closed-form capital structure solutions were derived and for simplicity, debt maturities were assumed to be infinite. CoCos were found to provide the bulk of tax shield benefits of straight debt while providing similar protection as equity. Albul et al. (2010) concluded that CoCos should be substituted for straight debt in bank capital.

Pennacchi (2010), also using a structural approach, modelled a bank balance sheet comprising short-term deposits priced at par (long-term bonds were ignored for tractability reasons), common equity and CoCos. The ratio of the asset value to the combined CoCo and equity value - assuming costless bankruptcy - was chosen as the CoCo trigger.

1.Although yields decrease because of the embedded optionality, this decrease is outweighed by increase in yield due to the extra risk associated with the convertibility possibility. In totality, yields increase. 
CoCos triggered by equity market values could lead to either multiple equilibria or no equilibrium, unless there is no value transfer between bank equity and contingent debt at conversion (see Calomiris \& Herring 2013; Pennacchi et al. 2011; Sundaresan \& Wang 2012). A continuous-time framework indicated that the condition necessary and sufficient to guarantee a unique equilibrium was the no value transfer condition.

In 2009, three banks issued securities that were considered to be CoCos. These instruments had triggers that were activated based on regulatory capital values. Lloyds Bank was the first to issue a CoCo in November 2009 in a successful subscription offer. The second recognised CoCo was issued by Rabobank in May 2010 and presented terms that dictated a 75\% writedown on the principal value of the bond when the bank's regulatory capital ratio fell to less than $7 \%$ with the remaining $25 \%$ stake being paid out in cash. The Rabobank CoCo does not exhibit the classic features of a $\mathrm{CoCo}$ in the sense that there is no equity conversion. The third CoCo bond issued was the security issued by Credit Suisse which was open to subscription from the public and offered a $7.875 \%$ coupon rate (a large credit spread at the time ${ }^{2}$ ) and was heavily oversubscribed. This CoCo was also to be converted from a bond to equity with a conversion cap of $\$ 20$ set to the amount at which it could be converted into shares.

Since their introduction, CoCos have, however, not been tested under the very market conditions for which they were designed to perform as loss-absorbing instruments. Theoretically there may be an untested weakness in the design of certain CoCos, beginning with the choice of trigger mechanism.

Both the Credit Suisse and Rabobank CoCos employ regulatory capital triggers which may prove to be problematic (Pennacchi et al. 2011). Regulatory capital is an accounting measure which is calculated internally by the finance department of a bank, usually on a quarterly basis. In a situation in which financial markets take a sudden and rapid decline, these quarterly reviews may prove to be too late to be effective. Consider, as an example, the mean and median tier 1 capital ratios for six banks in the US during the first four quarters of 2008, represented in Table 1 below.

The variation in these capital ratios would have proved ineffective leading indicators to illustrate distressed conditions during the financial crisis. Even with Lehman Brothers going bankrupt in Q4 of 2008, it is evident that many of the capital ratios of these banks even increased from their levels in Q1. It is thus highly improbable that CoCos with regulatory triggers would have been activated during the 2008 financial crisis. A second shortcoming pertains to the risk that CoCos may not convert from debt to equity while the bank is still a going concern. The regulatory nature of the triggers for the Rabobank and Credit Suisse CoCos

2.At the issue date, the 30 -year Treasury yield was $4.16 \%$, the AAA corporate bond yield was $5.26 \%$, and the BBB (which was Fitch's rating of the CoCo) corporate bond yield was $6.14 \%$.
TABLE 1: Tier 1 capital ratios for banks in the United States for the first four quarters of 2008

\begin{tabular}{lcccc}
\hline Bank & \multicolumn{4}{c}{2008} \\
\cline { 2 - 5 } & Q1 & Q2 & Q3 & Q4 \\
\hline Bank of America & 6.08 & 6.80 & 6.10 & 7.47 \\
Bank of NY Mellon Corporation & 7.44 & 7.94 & 8.00 & 11.90 \\
Capital One & 9.48 & 9.90 & 10.58 & 12.46 \\
Citigroup & 5.83 & 6.79 & 6.14 & 9.48 \\
JP Morgan Chase & 7.01 & 6.86 & 6.91 & 8.94 \\
Wells Fargo & 6.69 & 6.53 & 6.45 & 5.98 \\
\hline
\end{tabular}

Q, quarter.

Source: Thomson Reuters, 2017, Online database, viewed 13 May 2017, available from https://www.thomsonreuters.com/en.html

may cause them to remain as debt even when the banks are no longer going concerns. The function of CoCos in this study is to trigger debt into equity, prior to a non-viable condition of a bank to prevent liquidation rather than just softening the post-bankruptcy impact. The approach taken by Flannery (2005) discusses securities suitable for this purpose, for which the CoCo trigger mechanism is linked to a market-based value of the issuing bank's equity.

As an example, the CoCo issued would convert into equity when the share price is at a certain level. The goal in setting up this specified share price is to obtain a share price, when historically, the bank was in a bad financial position, but not yet in a non-viable condition. Flannery (2005) proposes that the CoCo investor receives several shares valued at the trigger price of the issued shares, equal to the bond's par value prior to conversion. While the market-based trigger appears better suited to the notion of a $\mathrm{CoCo}$, which will convert while a bank is still a going concern, it is not free from criticism. The risk of a market-based trigger lies in the potential for market manipulators to influence the share price of the issuing bank to trigger the CoCo conversion. It is theorised that CoCo investors will short-sell the stock of a company to drive the stock price down to a level well beneath their fundamental values for the sake of profiting from a CoCo trigger, thereby providing an incentive for certain CoCo investors to manipulate share prices (McDonald 2010). ${ }^{3}$

To combat the weaknesses inherent to CoCos, various solutions have been proposed. Kashyap, Rajan and Stein (2008) propose that banks do not issue loss-absorbing securities such as CoCos, but rather purchase insurance against falling capital levels. This would, however, require an insurer that is free from systemic risk which may be the case when a bank is irresponsible, but is not the case in a global financial crisis. Such an insurer will most likely also be under stress in a financial crisis and may not be able to meet its obligations (Duffie 2010).

Pennacchi et al. (2014) augment the Pennacchi (2010) framework by introducing COERCs, which permit the bank's original shareholders to buy back the shares at the bond's

3.For a comprehensive overview of the issue surrounding market manipulation of CoCo trigger designs, refer to: Albul et al (2012), Bolton and Samama (2011) CoCo trigger designs, refer to: Albul et al (2012), Bolton and Samama (2011),
Calomiris and Herring (2013), Flannery (2009a), Pennacchi et al. (2011), Culp (2009) Calomiris and Herring (2013), Flan
and Sundarsen and Wang (2011). 
par value. Modigliani-Miller results are assumed to hold, so financial distress model costs were ignored. In this article, the application and structure (specifically the ideal trigger mechanism) of COERCs in an African market context are explored. COERCs may address most of the shortcomings of traditional CoCos while still affording fixed-income investors the opportunity to invest in this security.

\section{Call Option Enhanced Reverse Convertible bonds}

Pennacchi et al.'s (2014) proposed CoCo design addresses the contradictory objectives of the relevant parties, namely regulatory authorities, CoCo investors and issuers. Although covered in detail in Pennacchi et al. (2014), a summary of these design features is given in Table 2.

\section{Data and methodology}

The data used for the analysis that follows and the methodology required is discussed below.

\section{Data}

The data used were simulated, stylised values for a standard COERC. No market parameters are required, such as equity or debt levels or market volatility. Details of the stylised example are provided in Table 4 and Table 5 in the 'results and discussion' section.

\section{Methodology}

COERCs are different from other CoCo structures in the way new equity is issued and the volume of this new equity. This arises from the opposing way new equity is issued as shown in Figure 3.

Criticisms levelled at COERCs have been addressed (Pennacchi et al. 2014). These criticisms and responses are presented in Table 3.

We note, however, that the COERC and market behaviour must be considered jointly. COERCs are akin to a bond plus a short position in a knock-in call option, struck well below the knock-in level. Assuming market behaviour which evolves in time by simple diffusion implies low risk, but market behaviour is characterised by occasional discontinuous jumps so COERCs are not entirely default-free.

The mathematics governing the pricing of COERCs is covered in detail by Pennacchi et al. (2014). The valuation of a COERC may be undertaken using a simple comparative example. This is detailed in the 'results and discussion' section, using a simple, stylised but realistic, numerical example.

\section{Results and discussion}

All figures in this section stem from the stylised example assumptions set out in Table 4 for CoCos and then moving on to Table 5 which sets out numerical assumptions governing COERCs.

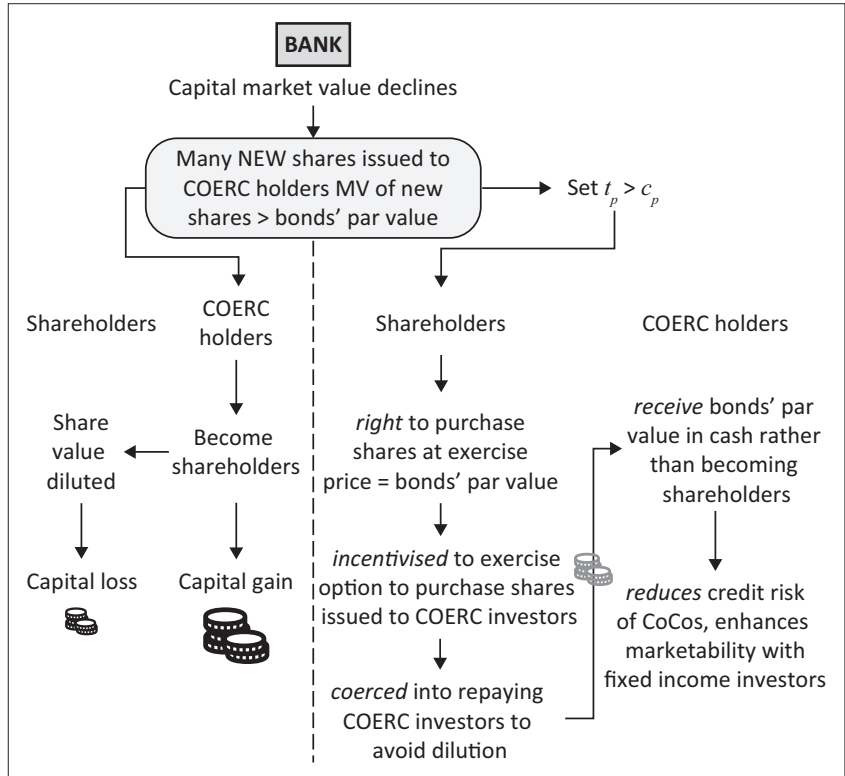

Note: The left-hand side represents the naïve scenario, the right-hand side displays the more likely outcome of Call Option Enhanced Reverse Convertible share conversion.

FIGURE 3: Principal benefits of Call Option Enhanced Reverse Convertibles.

TABLE 2: Summary and comparison of contingent convertible debt and Call Option Enhanced Reverse Convertible design features.

\begin{tabular}{|c|c|c|}
\hline Feature & CoCos & COERCS \\
\hline Trigger based on & Regulatory capital ratio. & - Market value capital ratio. \\
\hline $\begin{array}{l}\text { Market-based } \\
\text { triggers }\end{array}$ & $\begin{array}{l}\text { Unjustifiable conversions because of manipulation } \\
\text { or panic avoided because regulatory triggers } \\
\text { (not market-based triggers) apply. }\end{array}$ & $\begin{array}{l}\text { - Panic conversions avoided because equity holders have the option to purchase shares from } \\
\text { bondholders at conversion price. Thus, shareholders can prevent dilution by subscribing to a } \\
\text { rights issue with subscription price = conversion price. Proceeds may be used to repay debt. }\end{array}$ \\
\hline $\begin{array}{l}\text { Conversion and } \\
\text { trigger price }\end{array}$ & $\begin{array}{l}\text { Conversion price close to trigger price - makes } \\
\text { valuation difficult. Little shareholder incentive to } \\
\text { repay debt. } \\
\text { Higher risk decreases liquidity. }\end{array}$ & $\begin{array}{l}\text { - Conversion price significantly below trigger price so COERC relatively easy to value. Shareholders } \\
\text { have a large incentive to prevent dilution and repay debt. } \\
\text { - Low risk should improve liquidity, minimise the likelihood of financial distress, and make it } \\
\text { appealing to many risk-averse investors. }\end{array}$ \\
\hline Regulatory role & $\begin{array}{l}\text { Regulators are chief decision-makers in the } \\
\text { triggering of the conversion. }\end{array}$ & - No regulatory involvement. \\
\hline $\begin{array}{l}\text { Conversion and } \\
\text { debt repayment }\end{array}$ & $\begin{array}{l}\text { No guarantee shareholders will repay debt } \\
\text { because repayment in cash not guaranteed; } \\
\text { no guarantee of favourable tax treatment. }\end{array}$ & $\begin{array}{l}\text { - Because conversion price is significantly below trigger price, shareholders will almost always } \\
\text { prevent conversion and repay debt. Should result in favourable US tax treatment (COERC investors } \\
\text { will almost always be repaid in cash). }\end{array}$ \\
\hline $\begin{array}{l}\text { Multiple equilibria } \\
\text { problem }\end{array}$ & $\begin{array}{l}\text { High risk because trigger is based on regulatory } \\
\text { capital ratio. }\end{array}$ & $\begin{array}{l}\text { - Avoided because trigger is based on market value capital ratio (sum of [market values of equity + } \\
\text { COERCS]/senior debt). }\end{array}$ \\
\hline Loss absorption & Yes. & $\begin{array}{l}\text { - Although COERCs are not loss-absorbing, they encourage banks to issue equity and repay debt } \\
\text { when in financial distress. } \\
\text { - Commitment is made ex ante, so shareholders benefit through lower borrowing rates and conflicts } \\
\text { between shareholders and debtholders are minimised. }\end{array}$ \\
\hline
\end{tabular}

CoCos, contingent convertibles; COERCs, Call Option Enhanced Reverse Convertibles. 
TABLE 3: Potential criticisms of Call Option Enhanced Reverse Convertible issuance and measured responses.

\begin{tabular}{ll}
\hline COERC criticism & Response \\
\hline Hard to value. & - With the appropriate trigger mechanism, multiple equilibria are avoided. COERCs are designed to be nearly default-free - \\
Unattractive to traditional fixed-income investors. & relatively easy to value.
\end{tabular}

CoCos, contingent convertibles; COERCs, Call Option Enhanced Reverse Convertibles.

TABLE 4: Assumptions underlying a numerical contingent convertible debt example.

\begin{tabular}{lll}
\hline Parameter & Symbol & Value \\
\hline Assets & $A$ & 1100 \\
Liabilities (senior debt) & $D$ & 1000 \\
CoCo bond par value & $B$ & 30 \\
Current share price & $S_{0}$ & 10 \\
Number of shares outstanding & $n_{0}$ & 7 \\
On reaching trigger, CoCo converts to & Common stock shares & 6 \\
Current common shareholders' equity & $M V_{0}^{E}=S_{0} \times n_{0}$ & 70 \\
Market value of CoCo bond & $V=B$ (par value) & 30 \\
Market value of total capital & $S \times N_{0}+V$ & 100 \\
\hline
\end{tabular}

CoCo, contingent convertible.

Note: Assume at time $t$ that $S_{0}$ has fallen to 5 - the trigger price - so $S_{t}=5$

TABLE 5: Assumptions underlying a numerical Call Option Enhanced Reverse Convertible example.

\begin{tabular}{lll}
\hline Parameter & Symbol & Value \\
\hline COERC par value & $\mathrm{B}$ & 30 \\
Market value of COERC & $V=B$ (par value) & 30 \\
\hline
\end{tabular}

Note: Omitted values in Table 5 are assumed identical to those in Table 4.

COERC, Call Option Enhanced Reverse Convertible.

\section{Scenario 1: Conversion price $\left(c_{p}\right)=$ trigger price $\left(t_{p}\right)=5$}

$M V_{0}^{E}$ falls to $S_{t} \times n_{0^{\prime}}$ so $M V_{t}^{E}=35$ and the CoCo is triggered, converting into 6 additional shares. The total amount of shares outstanding, $n_{t}=n_{0}+6=13$.

If CoCo investors realise that the true value of the firm's assets is still 1100, then they know that the combined value of CoCo investors' and shareholders' stakes is 100 . The fundamental stock value per share is thus $\frac{100}{13}=7.69$ and the consequent gain to CoCo investors is $7.69 \times 6-30=16.15$ (a gain of $54 \%$ relative to the bond's market value of 30 prior to conversion).

This gain comes at the expense of the original shareholders who now own 7 shares trading at 7.69 rather than 10 , that is, a loss of 16.15 .

\section{Scenario 2: $c_{p}(5)<t_{p}(8)$}

If investors again believe that CoCos will convert into 6 shares, the number of shares will again increase to 13 , implying a stock price of $\frac{100}{13}=7.69$.
As the 8 trigger is reached, conversion occurs and the 10 stock price is no longer a unique equilibrium price. At 7.69, the 6 shares owned by CoCo investors represent a wealth transfer of $7.69 \times 6-30=16.15$ at the expense of the original shareholders. This value transfer makes the stock price fall below the trigger price. Two stock prices are thus possible, 10 and 7.69. This has also been discussed in Liebenberg et al. (2016).

Note that some assumptions about investor behaviour have been imposed here. Price manipulation beyond a fair value assumes the irrational behaviour of investors, while the assumption that shareholders will exercise their right to limit dilution argues for the rational investor behaviour.

\section{Scenario 1: At time $t, S_{0}$ has been manipulated down to 5 - the trigger price - so $S_{t}=5$}

The consequence of the conversion rate is that the COERC implied conversion price is significantly below the trigger price: that is, 1 rather than 5 .

The COERCs convert into 30 new shares. Combined with the 7 shares owned by initial shareholders, the number of shares outstanding is now $30+n_{0}=37$. This results in a fundamental (non-manipulated) share value of $\frac{100}{37}=2.70$.

Shareholders have the right to repurchase these shares at R1 (so that the total payment to COERC investors is 30) so they will do so. Were shareholders not to invoke this right, their wealth would fall from $7 \times 10=70$ to $7 \times 2.70=18.90$, a loss of $51.10(73 \%)$. This loss may be recovered by repurchasing the 30 shares at 1 from bondholders (which, at 2.70 per share is a gain of 51.10). The result is that COERC investors are paid their bonds' par value.

\section{Scenario 2: At time $t, S_{0}$ has justifiably fallen to $5(t p)$, so $S_{t}=5$}

This implies a fall in market value of equity from 70 to $S_{t} \times n_{0}=35$. COERC bondholders will convert into 30 shares. The fully diluted value per share is now $\frac{30+35}{37}=1.76$ per share. Shareholders will again exercise the option to repurchase 
the shares back at R1, so that COERC investors continue to receive their bonds' par value.

Shareholders will always repay COERC bondholders until the fully diluted stock price $=1$. This will be the case when the combined value of COERC bonds and initial shareholders' equity $=37$. As COERCs are repaid 30, equity is worth 7 and total value of the assets $=1000+37=1037$. So, provided the total value of the firm is greater than 1037, COERC investors are repaid their par value.

This explains why a larger proportion of shares are issued to COERC investors, which renders them less credit-risky. Suppose, instead, that only 6 shares were issued to COERC investors at conversion (as with CoCos, Table 3), so that conversion and trigger prices are both 5 . Shareholders would not purchase the 6 shares from COERC investors for a total sum of 30 unless the fully diluted stock price were 5 . For this to be the case, the total firm asset value must be $1000+13 \times 5=1065$.

If $A$ is less than 1065, shareholders will not exercise the option and COERC investors will retain 6 shares worth less than 5 (thus realising a loss from their bonds' par value). With a 1 conversion price, so that 30 shares are issued to COERC investors, they would become shareholders only if firm value falls to less than 1037. Lowering the conversion price thus reduces a COERC's credit risk.

Figure 4 compares COERC versus straight debt payoff profiles, assuming conversion and that the option to repurchase only occurs at the COERC bond's maturity. The bond payoff (par value 30) and shareholders payoff as a function of the firm's total asset value at the bond's maturity date are presented. The firm has senior debt of 1000 , so other claims are rendered worthless if firm value is less than 1000 . The solid line indicates payoffs for non-convertible bonds and the dashed line shows the payoff for COERCs.

The value $V$ of non-convertible bonds is worth 30 , provided the total firm asset value, $A$ is greater than 1031. If $A$ is between 1000 and 1030, shareholders lose everything, and bondholders receive $A-1000$ (i.e. the value of equity, $M V^{E}=$ $\max [A-1030,0]){ }^{4}$

In the case of convertible bonds with $c_{p}=1$ when $S_{t}=5$ or whenever firm value is greater than 1065 , equity holders exercise the call option and repay the bonds at par (provided the fully diluted stock price $>1$, or provided total firm value $>$ 1037; until that point is reached, nothing changes compared to the case where the debt was not convertible).

When the firm's value is less than 1037, shareholders will not bail out COERC bondholders, who now end up with $\frac{30}{37}$ of $\max [A-1000,0]$, that is, less than 30 . Shareholders obtain the residual, that is, $\frac{7}{37}$ of $\max [A-1000,0]$. A fundamental 4.The bonds worth 30 are subordinated to the bonds worth 1000 .

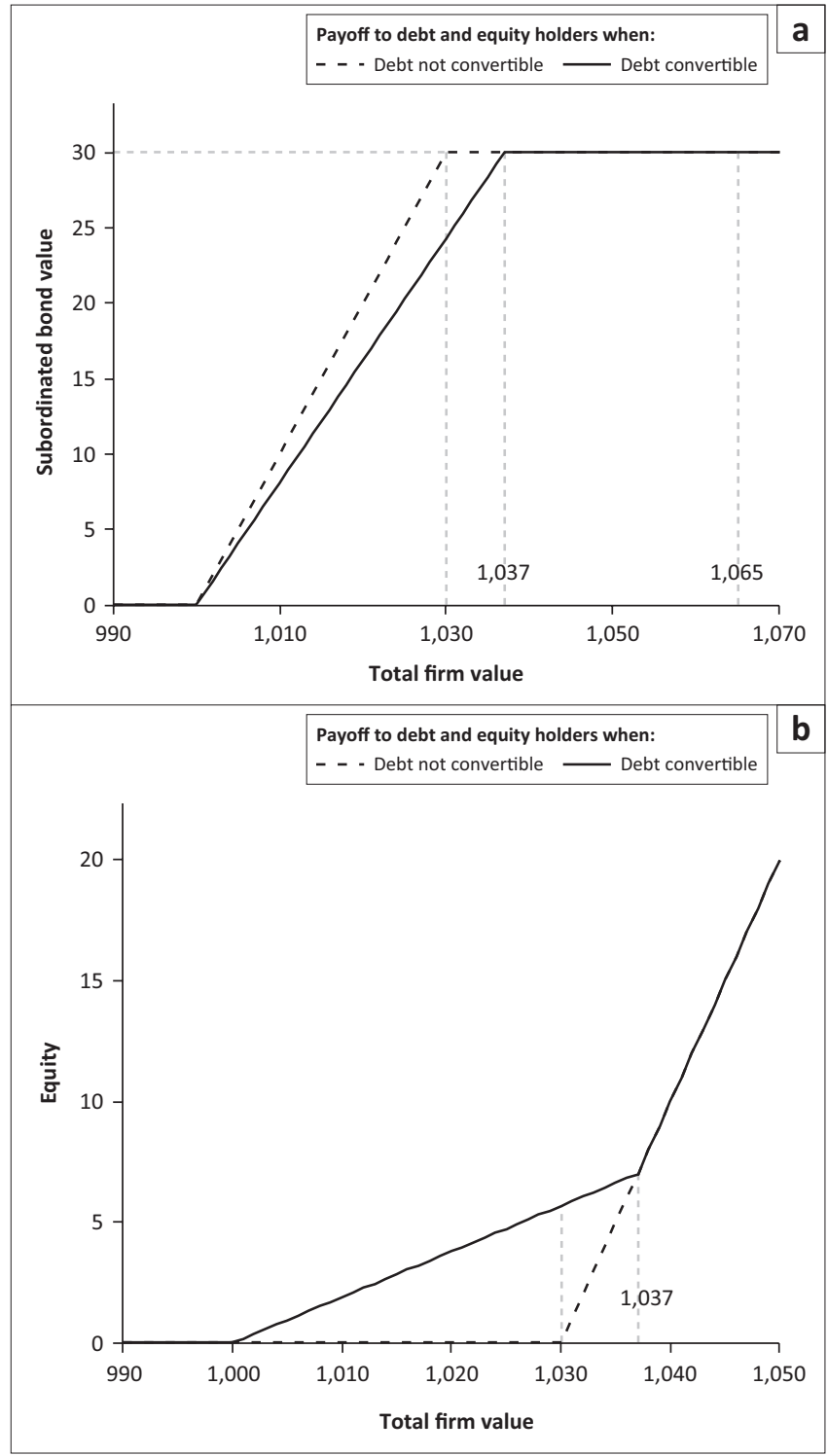

FIGURE 4: Comparison of Call Option Enhanced Reverse Convertible and straight debt payoff profiles: (a) subordinated bond value and (b) equity.

change is that now shareholders seek to preserve firm value between 1000 and 1037 as a direct consequence of the fact that the COERC investors must share the value of the firm with the equity holders whenever firm value is between 1000 and 1037. We have again assumed that shareholders will behave rationally in this instance.

By allowing the conversion price to be low (1) COERC bondholders' risk should be only slightly higher than that of non-convertible bonds. ${ }^{5}$ For $c_{p}$ and $t_{p}=5$, shareholders would refuse to repay debt when firm value is less than 1065, not when firm value is less than 1037. In that case, bondholders' risk would have been higher.

The market value of equity, number of shares issued and fundamental stock values - as a function of the share price are provided (for this example) in Figure 5. Figure 5a shows the gradual erosion of equity value (from R70 to R37) as the 5.More empirical, market-based observations are required to establish this assertion conclusively. 

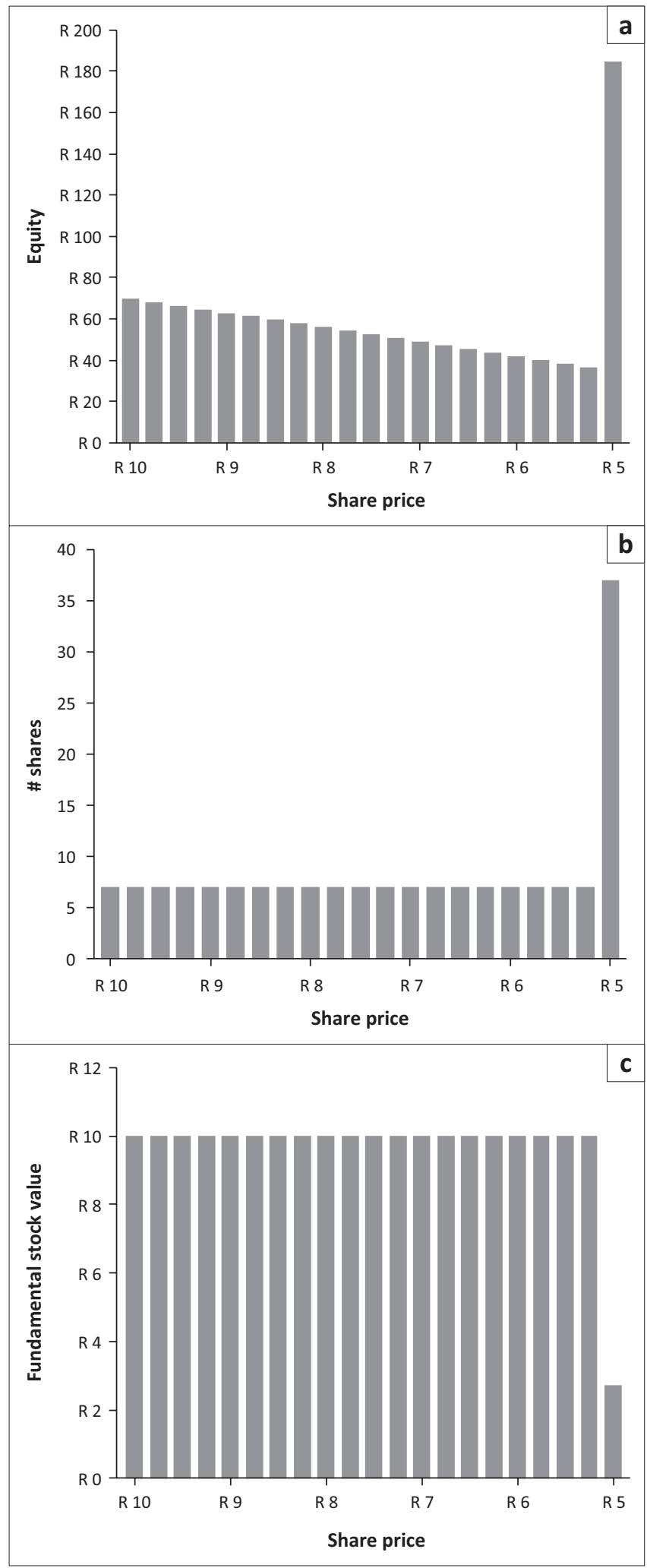

FIGURE 5: (a) Equity value, $M V^{E}$, (b) number of shares in issue and (c) fundamental share value, $S_{t}$ as a function of underlying share price. All descriptive parameters as given in Table 3. $c_{p}=t_{p}=\mathrm{R} 5$.

share price decreases and then, as the trigger price is reached (R5), conversion occurs and an accompanying sharp equity value increase (to R185 = $37 \times \mathrm{R} 5$ ). Figure $5 \mathrm{~b}$ shows the number of shares as a function of share price. As the share price decreases towards the trigger value, the number of shares (7) remains unaltered. At conversion, 30 new shares are issued, so the new number of shares is 37 . Figure 5c shows the decrease in fundamental stock value, from R10 per share prior to conversion to R2.70 after conversion.

Figure 6 displays 3D results from the stylised example. In each case, the relevant parameter is on the vertical axis as a function of number of shares issued and COERC conversion rate. Figure $6 \mathrm{a}$ demonstrates the influence of the number of shares in issue and the number of shares into which the COERC converts on the fully diluted share price, $S_{p}$. The lower the number of these variables, the higher $S_{p}$.

Figure $6 \mathrm{~b}, \mathrm{c}$ and e show that only the number of shares into which the COERC converts affects the gain to CoCo investors, the fundamental stock value and the implied conversion price. The number of shares in issue has no influence over these variables.

Figure $6 \mathrm{~d}$ shows the effect of the number of shares in issue and the number of shares into which the COERC converts on the exercise intention if the asset value is below certain values. For low values for these variables, the conversion threshold is lowest. As the number of shares in issue increases, the conversion threshold increases dramatically, but only for low COERC to shares conversion rates. For high values of this variable, the conversion threshold is low and unaffected by the number of shares in issue.

\section{Additional recommendations regarding Call Option Enhanced Reverse Convertible structures}

Developed economy corporate investment-grade bond yields and sovereign yields remain at historic low levels (e.g. $\approx 2.4 \%$ for corporate bonds, $\approx 2.3 \%$ for US 10-year Treasury yields and $\approx 1.3 \%$ for UK 10-year gilt yields in November 2017): investors have thus been driven into equities and real estate, fuelling potential bubbles in both asset classes (Mackintosh 2017). The prevalence of these low interest rates (see Figure 7) in the current (2018) developed economy environment (which have persisted for about a decade since the onset of the 2008-2009 credit crisis) allows considerable flexibility for COERC issuance (and CoCo issuance in general). The implication of low interest rates is relatively low CoCo coupon rates: banks do not have to attach exorbitant coupons to $\mathrm{CoCos}$ to render them more attractive to potential investors.

In emerging markets, particularly African markets, government yields are high by global standards: Figure 8 shows these yields for South African and Nigerian government 10-year bond yields.

Corporate bond yields in these African countries are a few percentage points higher still. These attractive interest rates are tainted by low credit ratings $(\mathrm{BB}+$ for South Africa and B+ for Nigeria): both countries currently (2018) have junk credit status (Fitch Ratings 2017a, b). Large African banks are, however, relatively sophisticated and most are Baselcompliant with strong capital levels (Oduora, Ngokab, \& Odongob 2017). COERCs would provide all the benefits 


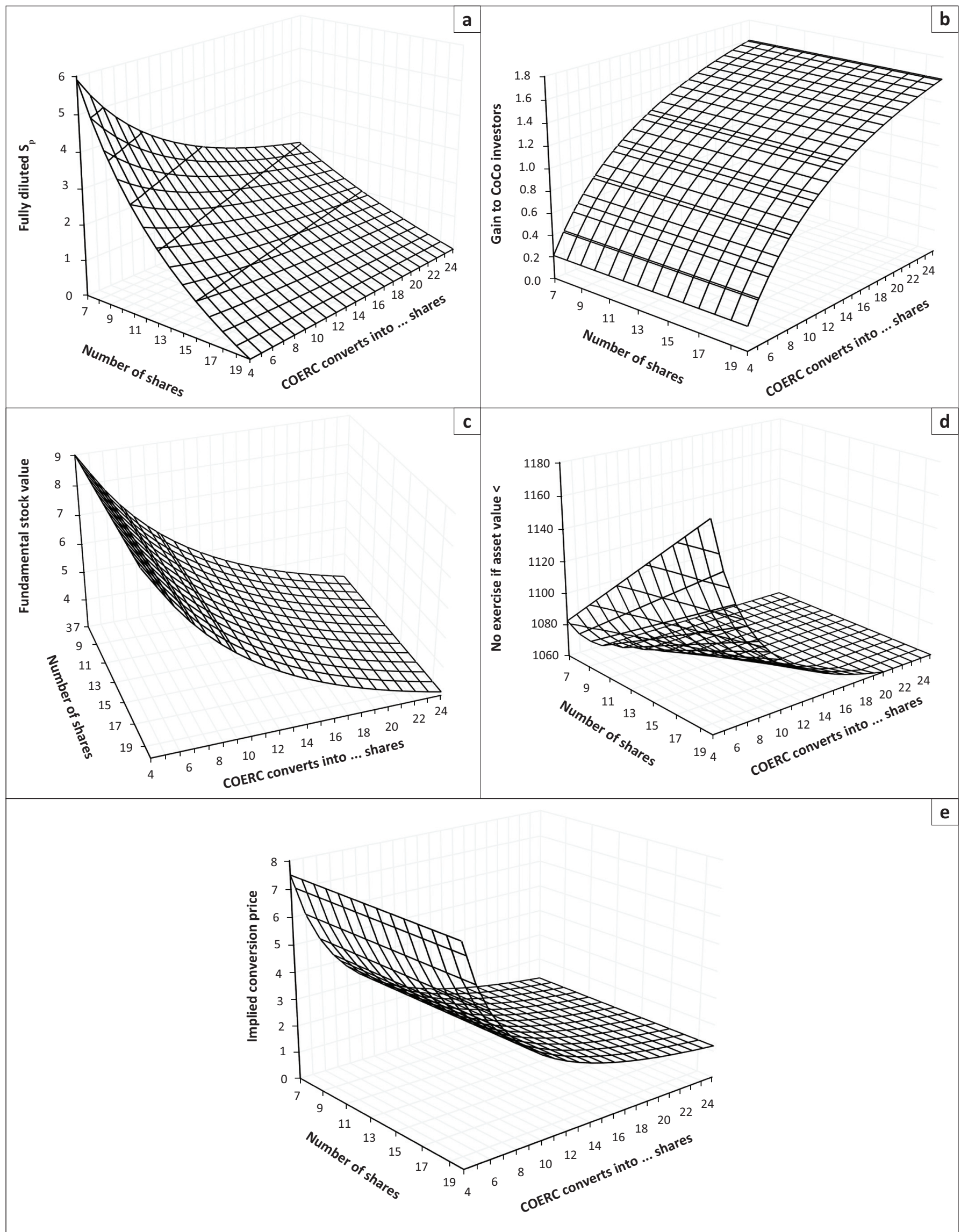

FIGURE 6: (a) Fully diluted share price and (b) gain to Call Option Enhanced Reverse Convertible investors as a function of the number of shares in issue and the Call Option Enhanced Reverse Convertible conversion rate, (c) fundamental stock value and (d) option exercise threshold as a function of the number of shares in issue and the Call Option Enhanced Reverse Convertible conversion rate, (e) implied conversion price, $c_{p}$, as a function of the number of shares in issue and the Call Option Enhanced Reverse Convertible conversion rate. 


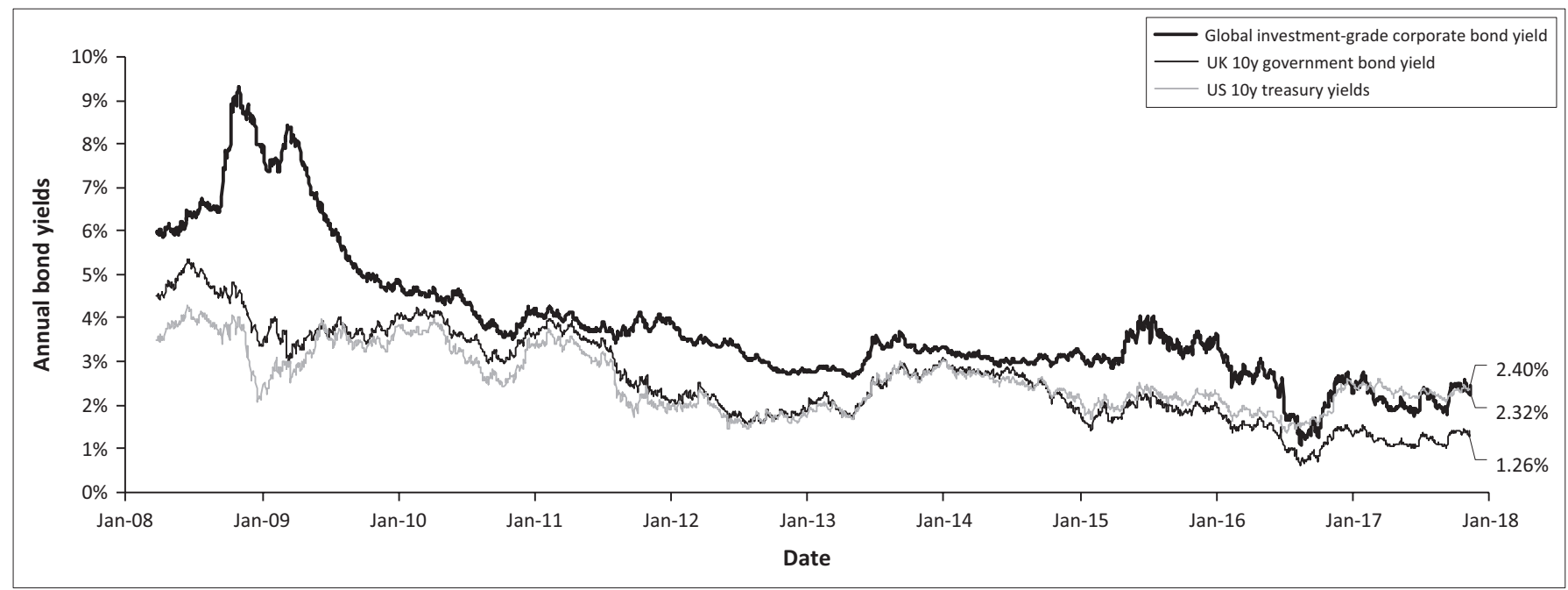

Source: Thomson Reuters, 2017, Online database, viewed 13 May 2017, available from https://www.thomsonreuters.com/en.html

FIGURE 7: Developed economy bond yields since 2008.

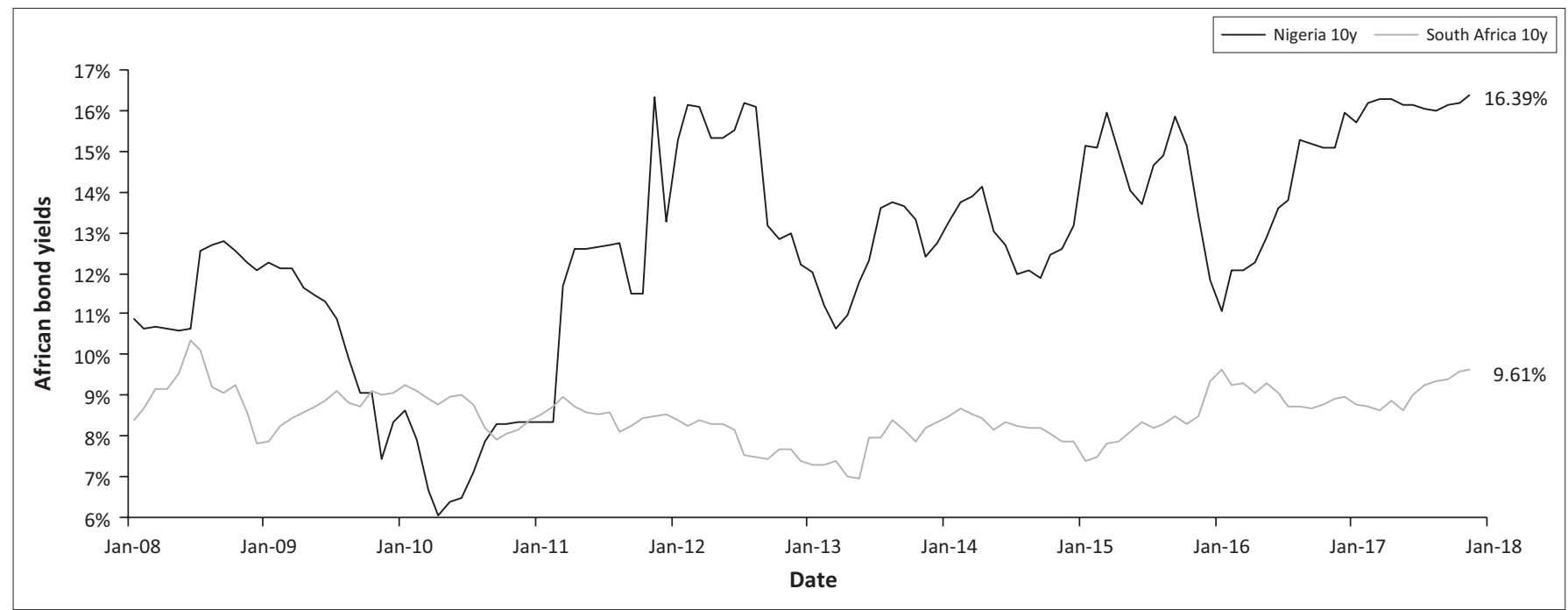

Source: Thomson Reuters, 2017, Online database, viewed 13 May 2017, available from https://www.thomsonreuters.com/en.html

FIGURE 8: South African and Nigerian government bond yields since 2008.

argued for in this article and have the added benefit of offering highly attractive yields. Given the current paucity of global high-yield assets, such instruments could even attract foreign investors.

From the examples provided in the 'results and discussion' section, it is evident that COERCs hold significant advantages to both investors and existing bank shareholders, as there is an incentive for existing shareholders to repurchase shares that will be issued when the COERC converts. The inherent purpose of CoCos (and COERCs) is to bolster capital levels when the bank suffers financial distress. With this in mind, the COERC coupon could also be designed such that it also assists with the bolstering of the bank's financial position, as the bank's share price decreases towards the trigger share price.

Consider a COERC with a floating coupon mechanism, in which the COERC pays a reduced coupon to investors as the share price approaches the trigger price. As an example, assume the COERC was issued with a coupon rate of $8 \%$, at a market share price of 50 and a trigger price of 25 . Assume the mechanism is constructed to decrease by 10 basis points at a share price of 38, and a further 10 basis points for every decline of 1 of the share price. In this scenario, once the price reaches 30 (coupon strike price), coupon payments will have been reduced to 0 , even though the COERC has not yet been triggered. Conversely, should the share price rise, coupon payments could restart using the same approach (an increase of 10 basis points) in the coupon payment for a share price of 21 , with an increase of 10 basis points for every increase of 1 above the level of 21 - up to a ceiling level of $8 \%$ at a share price of 28 and upward. This structure could provide even further assistance to banks in financial distress and may even (depending on the volume of COERCs that have been issued) assist the bank to avoid a COERC trigger entirely. Such a mechanism would only work in a relatively high interest rate environment (and in which the coupon rate at the upper end of the range was attractive to investors) - that is, perfectly suited for current African markets. 
Another example of a COERC with a floating coupon design could be one with a binary outcome in terms of the coupon rate. Consider a COERC with the same parameters as above (current share price, trigger share price and coupon rate). The issuers may add a property to the coupon such that once the bank share price reached a level of 38 (coupon strike price), all coupon payments would become $0 \%$. In such a scenario, a time-based contingency on the re-instatement of the coupon payment could be installed, for example resuming coupon payments after a set period such as six months, or the issuers could determine that coupon payment will resume as normal once the share price reaches a predetermined level (ideally higher than the coupon strike price) such as 45 .

Both examples of floating coupons for COERCS above would aid in the objective of issuing a security that is countercyclical in nature, as banks would avoid having to pay coupons in times of distress. In the volatile financial markets throughout Africa, this may prove to be a vital addition to the existing benefits that COERCs offer to banks. In considering the various stakeholders of a COERC, this design would also have benefits to all parties involved. For a COERC investor, apart from the attractive credit spread, the security will almost never convert to equity which makes it a feasible option for institutional fixed-income investors. From the perspective of the bank, the floating coupon is an attractive mechanism, as it further bolsters the financial position of a bank in periods of financial distress (see also Liebenberg et al. 2016, 2017). Regulators would approve of the fact that the COERC is countercyclical in nature and loss-absorbing and current shareholders would benefit from the fact that their equity would not be diluted if the COERC reached the trigger share price.

\section{Conclusions and suggestions for future work}

The changes in regulation brought forth through both Basel II and Basel III, indicate the acute awareness that the BCBS has, regarding the ill effects of procyclical capital models which were prevalent within banks preceding and during the financial crisis. Interventions to combat the drainage of capital from banks include measures such as the CCB, as well as adjustments to the quantity and quality of capital required from banks. A deeper study into the application of these measures, however, has indicated that in developing economies such as the markets in Africa, the CCB in particular may not be completely adequate (Burra et al. 2014; Van Vuuren 2012) as there is a substantial time lag that should be taken into account before requirements are relaxed.

In addition to the recommendations of the Basel frameworks, CoCos have been considered as an additional measure to promote countercyclicality in terms of capital composition in banks. This is because CoCos are loss-absorbing when banks are under financial stress, as a CoCo will convert from a bond into equity when certain predefined conditions are met. CoCos have been criticised by academics
(Pennacchi et al. 2012) ${ }^{6}$, particularly from a trigger mechanism design point of view. Under certain conditions, there may be incentives for speculators to short bank shares and artificially drive down the share price in order to profit from the conversion to equity when the CoCo triggers. COERCs have been proposed as an alternative structure to CoCos as they offer distinct advantages to all stakeholders involved. COERCs are also a viable investment option to fixed-income investors who make up a large percentage of institutional investors who purchase the bonds that are issued by banks. COERCs augment previous CoCo proposals (Flannery 2009a, 2009b) to solve three outstanding problems:

- COERCs avoid the problem of manipulating the issuing firm's stock price or placing its stock in a death spiral tailspin, because of stock dilution concerns by providing shareholders an option to repurchase the shares from COERC investors at the conversion price.

- If CoCo investors are exposed to considerable risk, there will be few buyers. To reduce these risks, the relevant security must be so designed as to force shareholders to repay when financial distress becomes considerable. COERCs set conversion prices very low, below the stock price that triggers conversion. Not repaying COERC investors, dilutes shareholder stock value substantially and transfers wealth to COERC investors which then reduces COERC credit risk. ${ }^{7}$

- COERCs eliminate the problem of multiple equilibria (Bond, Goldstein \& Prescott 2010) by basing the conversion trigger on the market value of total capital to senior debt ratio, rather than the stock price. ${ }^{8}$

COERCs are designed to exhibit a potentially low credit risk, and as such the possibility is there that these bonds may lower direct and indirect costs of financial distress. Standard CoCos and non-convertible bonds have higher default risk than COERCs: COERCs' lower default risk mitigates the excessive risk-taking incentives typically present in levered firms. COERCs reduce the possibility of wealth transfers between investors and shareholders and thus assist in the solution of the high leverage debt overhang problem (Myers 1977). Reductions in agency costs also make COERCs attractive investments for corporations.

Regulatory authorities are not required to be part of the process of monitoring and managing COERCs, and they force equity holders to repay debt to prevent dilution. This anticipated commitment benefits shareholders through lower COERC yields. That converts to equity in times of financial distress.

We propose, in addition to the above, that the coupon payment mechanism of the COERCs issued by banks in Africa be altered so that they either cease to pay a coupon to investors,

6.For a comprehensive overview of the issue surrounding market manipulation of CoCo trigger designs, refer to: Albul et al (2012), Bolton and Samama (2011) Calomiris and Herring (2013), Flannery (2009a), Pennacchi et al (2011), Culp (2009) and Sundarsen and Wang (2011).

7.Credit risk may be understated here because the market manipulation issue is overstated (investors are assumed to behave rationally).

8.Multiple equilibria are always possible when comparing a security's fair value versus its market value. 
or reduce the amount (and burden) of coupon payments as the share price of the bank deteriorates. This alteration may prove to be a significant addition to the already attractive countercyclical and loss-absorbing properties that are inherent to COERCs.

In addition to the countercyclical nature of COERCs, further studies need to investigate the quantum and optimal level at which coupon rates should be altered. An investigation into the inverse scenario in which the coupon rate of a COERC increases as the share price falls, may also yield useful results, as this could make COERCs attractive to investors, who would receive a higher yield at times when there is a higher risk attached to the security. In addition, further research into the impact on the liquidity position of the bank as a result of lowered or ceased coupon payments may also yield valuable results.

\section{Acknowledgements Competing interests}

The authors declare that they have no financial or personal relationships that may have inappropriately influenced them in writing this article.

\section{Authors' contributions}

F.J.N.L. was responsible for the literature study and article composition, G.W.v.V. for the quantitative analysis and modelling and A.H. for the proofreading and editing of the article.

\section{References}

Ainsworth, S., 2017, Global CoCo issuance in 2017 will be on a par with previous year Moody's Investor Services, New York, viewed n.d., available from https://www. moodys.com/researchdocumentcontentpage.aspx?docid=PBC_1065162

Albul, B., Jaffee, D.M. \& Tchistyi, A., 2010, Contingent convertible bonds and capital structure decisions, working paper, Hass School of Business, University of California, Berkeley, CA, viewed n.d., available from http://faculty.haas.berkeley.edu/Tchistyi/ CCB.pdf

Baily, M.N., Litan, R.E. \& Johnson, M.S., 2008, 'The origins of the financial crisis, the initiative on business and public policy', Fixing Finance, Paper 3: November, The Brookings Institution, Washington, DC.

Basel Committee on Banking Supervision (BCBS), 2010a, Basel III: A global regulatory framework for more resilient banks and banking systems, Bank for International Settlements, Basel, viewed n.d., available from http://www.bis.org/publ/ bcbs189_dec2010.pdf

Basel Committee on Banking Supervision (BCBS), 2010b, Guidance for national authorities operating the countercyclical capital buffer, Bank for International Settlements, Basel, viewed n.d., available from http://www.bis.org/publ/ bcbs187.pdf

Basel Committee on Banking Supervision (BCBS), 2011, Global systematically important banks: Assessment methodology and the additional loss absorbency requirement, Bank for International Settlements, Basel, viewed n.d., available from http://www.bis.org/publ/bcbs201.pdf

Berg, T. \& Kaserer, C., 2015, 'Does contingent capital induce excessive risk-taking and prevent an efficient recapitalization of banks?', Journal of Financial Intermediation 24(3), 356-385. https://doi.org/10.1016/j.jfi.2014.11.002

Bond, P., Goldstein, I. \& Prescott, E., 2010, 'Market-based corrective actions', Review of Financial Studies 23(1), 781-820.

Bolton, P. \& Samama, F., 2012, 'Contingent capital and long-term investors: A natura match?', Economic Policy 27, 277-316.

Bolton, P. \& Samama, F., 2011, 'Capital access bonds: Contingent capital with an option to convert', conference paper, Economic Policy Fifty-fourth Panel Meeting hosted by the National Bank of Poland, Warsaw, 27-28 October. viewed n.d., available from http://zerodotnine.co.uk/wp-content/uploads/2013/03/bolton_samama.pdf

Burra, P., De Jongh, P.J., Raubenheimer, H., Van Vuuren, G., Wiid, H., 2014, 'Implementing the countercyclical capital buffer in South Africa: Practical considerations', South African Journal of Economic and Management Sciences 18(1), 105-127.
Calomiris, C. \& Herring, R., 2013, 'How to design a contingent convertible debt requirement that helps solve our too-big-to-fail problem', Journal of Applied Corporate Finance 25(2), 39-62. https://doi.org/10.1111/jacf.12015

Culp, C., 2009, 'Contingent capital vs contingent reverse convertibles for banks and insurance companies', Journal of Applied Corporate Finance 21(4), 17-27. https:// doi.org/10.1111/j.1745-6622.2009.00247.x

De Haas, R. \& Van Horen, N., 2012, 'International shock transmission after the Lehman Brothers collapse - Evidence from syndicated lending', European Bank for Reconstruction and Development working paper 42, EBRD, London.

Duffie, D., 2010, 'A contractual approach to restructuring financial institutions, Chapter 6', in G. Schulz, K. Scott \& J. Taylor (eds.), Ending bailouts as we know them, Hoover Institution, Stanford University, Stanford, CA, pp. 109-124.

Fitch Ratings, 2017a, Fitch affirms South Africa at BB+; Outlook stable, retrieved 12 December 2017, from https://www.fitchratings.com/site/pr/1032818

Fitch Ratings, 2017b, Fitch affirms Nigeria at B+; Outlook negative', retrieved 15 December 2017, from https://www.fitchratings.com/site/pr/1028516

Flannery, M., 2005, 'No pain, no gain: Effecting market discipline via reverse convertible debentures', in H.S. Scott (ed.) Capital adequacy beyond Basel: Banking, securities and insurance, Oxford University Press, Oxford, pp. 171-196

Flannery, M., 2009a, Market value triggers will work for contingent capital investments, working paper, University of Florida, Gainesville, FL.

Flannery, M., 2009b, Stabilizing large financial institutions with contingent capital certificates, working paper, University of Florida, Gainesville, FL.

Huang, H., 2009, 'Convertible bonds: Default risk and uncertain volatility', Bonn Economic Discussion Paper, University of Bonn, Germany, viewed n.d., available Economic Discussion Paper, University of Bonn, Germany, view
from http://ideas.repec.org/p/bon/bonedp/bgse09_2010.html

Herring, R.J., 2017, 'CoCos: A promising idea poorly executed. Achieving financial stability', World Scientific Studies in International Economics 61(2), 103-120. https://doi.org/10.1142/9789813223400_0009

Kashyap, A., Rajan, R. \& Stein, J., 2008, 'Rethinking capital regulation', paper prepared for FRB of Kansas City Symposium on Maintaining Stability in a Changing Financial System, Jackson Hole, Wyoming, 21-23 August, viewed n.d., available from https:// pdfs.semanticscholar.org/3d2c/e56fa3d0f97c991b8531204d605e2e38fbc3.pdf

Liebenberg, F., Van Vuuren, G. \& Heymans, A., 2016, ‘Pricing contingent convertible bonds in African banks', South African Journal of Economics and Management Sciences 19(3), 369-387. https://doi.org/10.4102/sajems.v19i3.1413

Liebenberg, F., Van Vuuren, G. \& Heymans, A., 2017, 'Contingent convertible bonds as countercyclical capital measures', South African Journal of Economics and Management Sciences 20(1), 1-17.

Mackintosh, J., 2017, 'Tech is no bubble, but the stock market might be', Wall Street Journal, 20 July, viewed n.d., available from https://www.wsj.com/articles/techis-no-bubble-but-the-stock-market-might-be-1500572064

McDonald, R., 2010, 'Contingent capital with a dual price trigger', Journal of Financia Stability 9(2), 230-241. https://doi.org/10.1016/j.jfs.2011.11.001

Merton, R., 1974, 'On the pricing of corporate debt: The risk structure of interest rates', Journal of Finance 29(2), 449-470.

Myers, S., 1977, 'Determinants of corporate borrowing', Journal of Financial Economics 5(1), 147-175

Nikolov, P.T., 2010, 'Procyclical effects of the banking system during the financial and economic crisis 2007-2009', Finance and Investments, 25 June. http://hdl.handle. net $/ 2105 / 22738$

Pennacchi, G., 2010, A structural model of contingent bank capital, working paper College of Business, University of Illinois, Champaign, IL, viewed n.d., available from http://business.illinois.edu/gpennacc/ConCap061811.pdf

Pennacchi, G., 2011, A structural model of contingent bank capital, working paper 1004, Federal Reserve, Bank of Cleveland, Cleveland, TN, viewed n.d., available from http://business.illinois.edu/gpennacc/ConCap061811.pdf

Pennacchi, G., Vermaelen, T. \& Wolff, C., 2011, 'Contingent capital: The case for COERCs', LSF Research Working Paper Series 10-08, Luxembourg School of Finance, University of Luxembourg.

Pennacchi, G., Vermaelen, T. \& Wolff, C.C.P., 2014, 'Contingent capital: The case of COERCs', Journal of Financial and Quantitative Analysis 49(3), 541-574. https:// doi.org/10.1017/S0022109014000398

RiskConcile, 2017, When a CoCo cracks ... Banco Popular case study, Risk Management Solutions, Newark, CA, viewed n.d., available from http://www.riskconcile.com/ $\mathrm{rc} / \mathrm{rd} /$ BancoPopular.html

Sundaresan, S., 2013, 'A review of Merton's model of the firm's capital structure with its wide applications', Annual Review of Financial Economics 5(1), 21-41. https:// doi.org/10.1146/annurev-financial-110112-120923

Sundaresan, S. \& Wang, Z., 2011, 'On the design of contingent capital with a market trigger', Federal Reserve Bank of New York Staff Report no. 448, May, viewed n.d. available from https://www.newyorkfed.org/medialibrary/media/research/staff reports/sr448.pdf

Sundaresan, S. \& Wang, Z., 2012, 'On the design of contingent capital with a market trigger', Journal of Finance 72(2), 881-920.

Thomson Reuters, 2017, Online database, viewed 13 May 2017, available from https://www.thomsonreuters.com/en.htm

Unmack, N., 2017, 'Going, going gone: Popular wipeout leaves CoCo bonds on drawing board', Reuters Breaking Views, 07 June, viewed n.d., available from https://www. breakingviews.com/considered-view/popular-wipeout-leaves-coco-bonds-ondrawing-board/

Van Vuuren, G., 2012, 'Basel III countercyclical capital rules: Implications for South Africa', South African Journal of Economic and Management Sciences 15(3), 309-323. 